\title{
PUBLIC PERCEPTION OF RISKS ASSOCIATED WITH CONTAMINATED GLASSWORKS SITES IN SOUTH-EASTERN SWEDEN
}

\author{
Monika Filipsson \\ Anna Augustsson \\ Sofia Nyholm \\ Linnaeus University, \\ Sweden
}

\begin{abstract}
Glass has been produced for centuries in Kalmar and Kronoberg Counties in south-eastern Sweden. This industry has lead to severe soil contaminations, particularly due to the historical use of lead, cadmium and arsenic. People may be exposed to heavy metals for example via direct soil contact or consumption of locally produced food. The residents' risk perception was investigated in this study. Do the public perceive a high risk for their own health, for future generations or for the environment, and are they worried? Is there a difference if you live close to the glass factory? Is there a desire for more information about possible risks? With the aim to answer these questions, a questionnaire was sent to 599 individuals in Kalmar and Kronoberg counties. In order to reach people living close to glassworks, half of the questionnaires were sent to randomly selected individuals in four small communities with glassworks and the other half to randomly selected individuals in the two counties. Two groups were compared, one with respondents living $1 \mathrm{~km}$ or closer and one living $1 \mathrm{~km}$ or more away from a glassworks. The results showed that the respondents were more concerned about risks for the environment than their health. People living close to the glassworks were more worried and perceived a higher risk for the environment, the health and for future generations compared to people living more than $1 \mathrm{~km}$ away from glassworks. There was no difference in trust in authorities or consultancies that work with risk assessments, but people that lived close to the glassworks were somewhat keener on having more information about possible risks. About half of the respondents in this group wanted more information about risks, which indicate that there may be a need for an improved risk communication and exchange of information between authorities, researchers and the public.
\end{abstract}

\section{KEYWORDS}

Risk perception, worry, risk communication, heavy metal contamination, glass industry 


\section{INTRODUCTION}

This study addresses how residents perceive environmental and health risks with soils that are polluted by production of glass in south-eastern Sweden, as well as if there is a desire for more information about these risks. In this area, which is called the "Kingdom of Crystal", glass has been produced at several glassworks for centuries. The use of for example lead, cadmium and arsenic has lead to severe land contamination in this area. Of the 20 most prioritized contaminated areas in Kalmar and Kronoberg Counties, 14 are glassworks sites [1]. Thus, soil pollutions in these areas may constitute a threat to human health and the environment.

Risk perception by people living close to polluted soils is an important aspect in the risk analysis process since it is of relevance for the possibility to establish a good relationship between for example authorities and the public and for the possibility to develop successful communication strategies [2]. Residents in this area may perceive risks with contaminated land in different ways.

Risk perception is often considered to involve intellectual judgments; worry on the other hand involves emotional responses [3]. Risk perception is in general affected by different factors, for example is the risk perceived to be high when it is involuntary, uncontrollable, unfamiliar, dread and pose a high risk to future generations [4,5]. A study on risk perception at metal contaminated land showed that people living close to the contaminant source perceive a higher risk compared to non-exposed people [6]. Risk perception may also differ because of factors such as gender $[7,8,9,10]$ and level of education [11]. Self-estimated knowledge has shown to affect risk judgments in the case of contaminated land [12].

In this study it is investigated how people perceive risks with contaminated glassworks sites and if there is a desire to obtain more information about these risks. In more detail, the study aim to answer the following questions:

1) Are people worried about risks due to contaminated glassworks sites and do they perceive a high risk for the health and the environment, and are there differences if they live close to glassworks or far away?

2) Do people consume fruit or vegetables from their own garden or a garden nearby, and tap water from private wells? Are they worried about that these food items are affected by contaminants from glassworks sites?

3) How severe do people find contaminated sites compared to other environmental problems, and do they find it important to clean-up these sites?

4) Do people trust authorities and consultants in their work with contaminated land issues? Is there a desire for more information about risks and from whom do they want information?

\section{METODS}

In November 2012 a questionnaire was sent to randomly selected individuals; 300 persons in Kronoberg and Kalmar Counties (Figure 1a) and 300 in four postal areas with glassworks (Orrefors, Kosta, Älghult and Eriksmåla) in south-eastern Sweden (Figure 1b). The individuals were selected via SPAR (Statens personadressregister) including data from the 


\section{Linnaeus ECO-TECH 14}

\section{Kalmar, Sweden, November 24-26, 2014}

Swedish Population Register ${ }^{1}$. One person was included in both groups and therefore were only 599 questionnaires distributed. The focus in this article is to compare the two groups with different distance to glassworks, in order to obtain a view of people's risk perception, worry and desire for more information about environmental and health risks in this area.

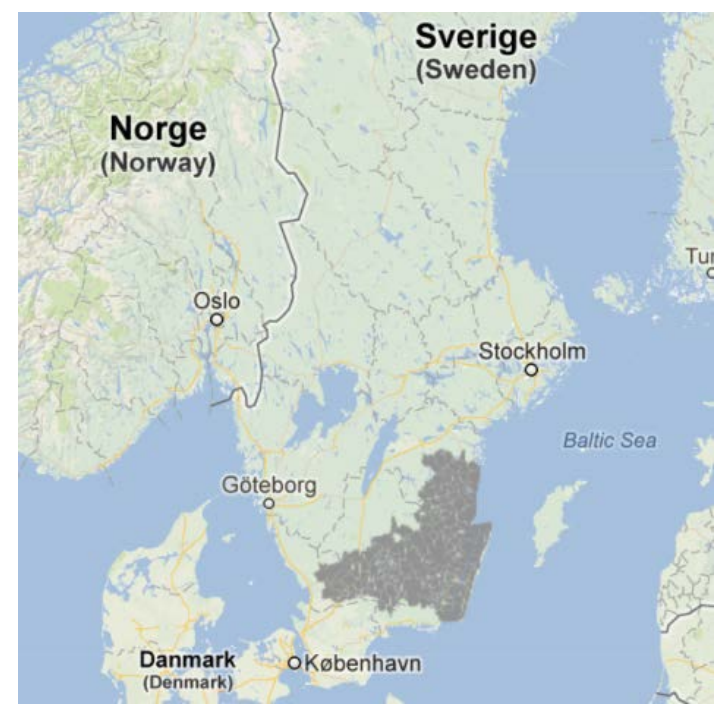

a. Kronoberg and Kalmar Counties

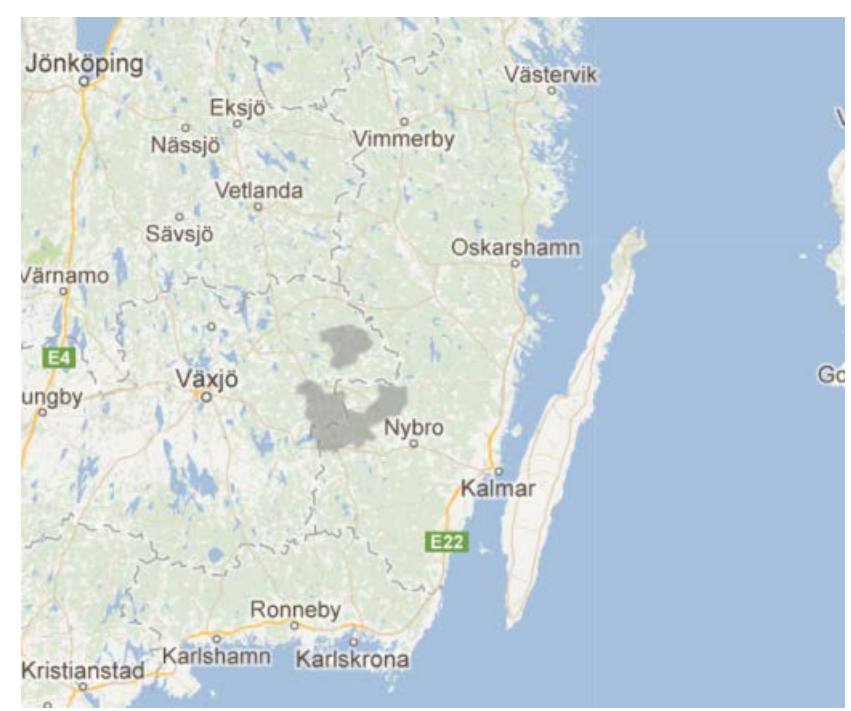

b. Orrefors, Kosta, Älghult and Eriksmåla

Figure 1. The study area in south-eastern Sweden.

The questionnaire included questions about self-estimated knowledge, risk perception, worry, contaminated soil in relation to other environmental issues, the importance to clean up these sites and trust (Table 1). The questions also investigated if people consumed fruit or vegetables from their own garden or a garden nearby and if they drank tap water from a private well (Table 2 and 3), as well as if people are worried about that these food items are affected by pollutions from glassworks (Table 1). It was also investigated if people want more information about environmental and health risks (Table 4) and from whom do they want information (Figure 2).

The answers were self-reported with a scale from 1 (do not agree at all) to 5 (totally agree), yes/no or multiple options. Descriptive statistics are presented in this paper. The two groups with different distance to glassworks are compared using t-tests, with a level of significance of $\alpha=0.05$, were performed using Microsoft Excel 2007. In the same way close connected questions are compared for the whole group (Table 1, Q7/Q8, Q9/Q10, Q9/Q15, Q9/Q16, Q15/Q16 and Q21/Q22).

\section{RESULTS AND DISCUSSION}

In total, 207 respondents answered the questions (35 \%); 78 of them live 0-1 km away from glassworks and 127 persons live $1 \mathrm{~km}$ or more from glassworks. Two individuals did not specified distance to nearest glasswork. The average age of the respondents was 57 years, and $56 \%$ were male and $44 \%$ were female. The majority of the respondents (68\%) did not have any occupational connection to glassworks while $19 \%$ worked or has worked at glassworks

\footnotetext{
${ }^{1}$ http://www.statenspersonadressregister.se
} 
and $13 \%$ had relatives that worked or has worked at glassworks. As expected, the respondents that lived near glassworks estimated their knowledge about pollution from glassworks higher than others (Table 1, Q6).

Many people, especially those living close to the glassworks, perceived a high risk and were worried in particular for the environment but also for the health and future generations (Table 1, Q7-Q11). Likewise, a study in Switzerland found that people exposed to soil contamination perceived a higher risk than the non-exposed group [6].

Table 1. Statements and questions about risks with contaminated glassworks sites. Average answers are presented with the scale from 1 (do not agree at all) to 5 (totally agree) with standard deviation within brackets.

Distance to glassworks

\begin{tabular}{|c|c|c|c|c|}
\hline $\mathrm{Q}$ & Statement/Question & All & $0-1 \mathrm{~km}$ & $1 \mathrm{~km} \mathrm{-}$ \\
\hline 6 & $\begin{array}{l}\text { I have good knowledge about pollutions from } \\
\text { glassworks. }\end{array}$ & $2.7(1.3)$ & $3.4(1.1)^{\mathrm{a}}$ & $2.3(1.1)^{\mathrm{a}}$ \\
\hline 7 & $\begin{array}{l}\text { I believe that there are health risks for those } \\
\text { living near pollutions from glassworks. }\end{array}$ & $3.2(1.2)^{b}$ & $3.6(1.2)^{\mathrm{a}}$ & $2.9(1.1)^{\mathrm{a}}$ \\
\hline 8 & $\begin{array}{l}\text { I believe that there are risks for the } \\
\text { environment due to pollutions from glassworks. }\end{array}$ & $3.6(1.2)^{b}$ & $4.1(1.2)^{\mathrm{a}}$ & $3.3(1.1)^{\mathrm{a}}$ \\
\hline 9 & $\begin{array}{l}\text { I feel worried about that pollution from } \\
\text { glassworks may affect the health. }\end{array}$ & $2.8(1.4)^{\text {cde }}$ & $3.1(1.4)^{\mathrm{a}}$ & $2.5(1.3)^{\mathrm{a}}$ \\
\hline 10 & $\begin{array}{l}\text { I feel worried about that pollution from } \\
\text { glassworks may affect the environment. }\end{array}$ & $3.3(1.3)^{\mathrm{c}}$ & $3.6(1.3)^{\mathrm{a}}$ & $3.0(1.3)^{\mathrm{a}}$ \\
\hline 11 & $\begin{array}{l}\text { I feel worried about that the health of future } \\
\text { generations may be affected by pollutions from } \\
\text { glassworks. }\end{array}$ & $2.9(1.3)$ & $3.3(1.3)^{\mathrm{a}}$ & $2.7(1.2)^{\mathrm{C}}$ \\
\hline 15 & $\begin{array}{l}\text { I feel worried about that fruit and vegetables } \\
\text { may be affected by pollutions from glassworks. }\end{array}$ & $2.2(1.3)^{d}$ & $2.5(1.3)^{\mathrm{a}}$ & $2.0(1.2)^{\mathrm{a}}$ \\
\hline 16 & $\begin{array}{l}\text { I feel worried about that tap water may be } \\
\text { affected by pollutions from glassworks. }\end{array}$ & $2.1(1.3)^{\mathrm{e}}$ & $2.1(1.4)$ & $2.0(1.3)$ \\
\hline 17 & $\begin{array}{l}\text { There are other environmental problems that } \\
\text { are more serious than contaminated soil. }\end{array}$ & $3.4(1.2)$ & $3.5(1.2)$ & $3.3(1.2)$ \\
\hline 18 & $\begin{array}{l}\text { It is important that soils contaminated by } \\
\text { glassworks activities are cleaned up. }\end{array}$ & $4.1(1.2)$ & $4.1(1.2)$ & $4.0(1.2)$ \\
\hline 21 & $\begin{array}{l}\text { I trust that authorities assessing and managing } \\
\text { the risks associated with contaminated } \\
\text { glassworks sites make accurate judgments. }\end{array}$ & $3.5(1.2)$ & $3.5(1.2)$ & $3.5(1.2)$ \\
\hline 22 & $\begin{array}{l}\text { I trust that consultants assessing and managing } \\
\text { the risks associated with contaminated } \\
\text { glassworks sites make accurate judgments. }\end{array}$ & $3.3(1.2)$ & $3.3(1.2)$ & $3.3(1.2)$ \\
\hline
\end{tabular}

${ }^{a}$ Significant differences when comparing the respondents due to distance to glassworks.

$\mathrm{b} / \mathrm{c} / \mathrm{d} / \mathrm{e}$ Significant differences in answers between questions. 


\section{Linnaeus ECO-TECH 14}

\section{Kalmar, Sweden, November 24-26, 2014}

People that lived 0-1 km away from glassworks were more worried about that fruit and vegetables may be affected by pollutions compared to those in the group living far away from glassworks (Table 1, Q15). Both groups were less concerned about exposure via tap water than they were for exposure via vegetable and fruit and there was no difference between the groups (Table 1, Q16). In this study, only these two routes of exposure were compared. But the results could still be compared with a study by Weber et al. that found that consumption of salad or vegetables from contaminated soil was perceived as the most dangerous exposure pathway followed by consumption of groundwater [6]. That study also included four other exposure pathways (inhaling soil gas, skin contact, contamination via stomach and meat from the region), all of which were perceived as less dangerous than exposure via vegetables and groundwater.

The worry about that fruit, vegetables or tap water may be affected by pollutions from glassworks was in average lower than worry for health or the environment in general (Table 1). But even though the average rating was lower, $13 \%$ of the respondents in in the group that lived 0-1 km from glassworks answered with 5 (totally agree) and 48\% answered 3, 4 or 5 on the statement that they felt worried about that fruit and vegetables may be affected by pollutions from glassworks. When it comes to tap water, 9\% answered with 5 (totally agree) and $34 \%$ answered 3, 4 or 5 on the statement that they felt worried about that tap water may be affected by pollutions from glassworks.

Many respondents consumed home-grown fruit and vegetables; $79 \%$ of all respondents consumed fruit and $72 \%$ consumed vegetables from their own garden or a garden nearby at least sometime per year (Table 2). Of the respondents that lived 0-1 km from glassworks, $82 \%$ consumed fruit and $65 \%$ consumed vegetables from their own garden or a garden nearby at least sometime per year. When it comes to drinking water, only $6 \%$ of the respondent that lived 0-1 km away from glassworks drank tap water from their own well (Table 3). A greater proportion, 34\%, of the respondent that lived $1 \mathrm{~km}$ or more away from glassworks drank tap water from a private well.

The fact that a large part of the respondents consumed home-grown fruit or vegetables calls for a further investigation of this exposure pathway. Our recent study showed that there are high concentrations of lead $(\mathrm{Pb})$ and cadmium $(\mathrm{Cd})$ in many private gardens in this area, but still the concentrations in potatoes and lettuce were only moderately elevated [13]. The present study shows that many people consumed vegetables and fruits from their own garden or another garden in the area. Together with information about that the uptake of metals depends on type of crop but also for example soil properties [14], it shows that it is important to investigate the uptake also in other crops and for other contaminants in order to assess exposure from home-produced food items.

Table 2. The part of respondents (\%) that eat fruit or vegetables grown in their own garden or a garden nearby.

\begin{tabular}{ll}
$\begin{array}{ll}\text { 12. Do you some time during the } & 13 . \text { Do you some time during the } \\
\text { year eat fruit grown in your own } & \text { year eat vegetables grown in your } \\
\text { garden or a garden nearby? } & \text { own garden or a garden nearby? }\end{array}$ \\
\hline
\end{tabular}


Linnaeus ECO-TECH` 14

Kalmar, Sweden, November 24-26, 2014

\begin{tabular}{lcccccc} 
& All & $0-1 \mathrm{~km}$ & $1 \mathrm{~km}-$ & All & $0-1 \mathrm{~km}$ & $1 \mathrm{~km}-$ \\
\hline Yes, regularly & 22 & 18 & 24 & 20 & 16 & 23 \\
\hline $\begin{array}{l}\text { Yes, several times } \\
\text { per year }\end{array}$ & 29 & 26 & 30 & 27 & 25 & 28 \\
\hline $\begin{array}{l}\text { Yes, sometime } \\
\text { per year }\end{array}$ & 28 & 37 & 23 & 25 & 25 & 25 \\
No & 21 & 18 & 23 & 28 & 35 & 24 \\
\hline
\end{tabular}

Table 3. The part of respondents (\%) that drink tap water from their own well.

\begin{tabular}{lcccc}
\hline & \multicolumn{2}{c}{ 14. Do you drink tap water from your own well? } \\
\cline { 2 - 4 } & & \multicolumn{2}{c}{ Distance to glassworks } \\
& All & $0-1 \mathrm{~km}$ & $1 \mathrm{~km}$ - \\
\hline Yes, from private drilled well & 15 & 5 & 21 \\
\hline Yes, from private dug well & 9 & 1 & 13 \\
\hline No & 76 & 94 & 65 \\
\hline
\end{tabular}

Even though the respondents did not indicated contaminated soil as the most important environmental problem, they still found it important that soils contaminated by glassworks are cleaned up (Table 1, Q17 and Q18). Before a contaminated area can be cleaned up, the risk is assessed and both authorities and consultants are often involved in that process. The public average scoring on the statement that the trust authorities and consultants were 3.3-3.5 and there was no difference in trust in authorities compared to consultants that work with risk assessment and risk management of contaminated land (Table 1, Q21/Q22). There was also no difference in trust when comparing the groups with different distance to glassworks.

Nearly half of the respondents wanted to have more information (Table 4, Q19), and the respondents prefer information from authorities (municipalities, Swedish Environmental Protection Agency (EPA), County Administrative Board) followed by glassworks, mass media and consultancies (Figure 2). Despite the fact that there was no difference in trust in authorities and consultants, the respondents clearly wanted to have information from authorities (Figure 2). The most common answer by the respondents that lived 0-1 km away was that they wanted to have information from municipalities which was not the case for the group that lived $1 \mathrm{~km}$ or more from glassworks. A few respondents stated that they wanted information from other sources including researcher, experts, people that are affected, independently reliable source or they did not know from whom.

Table 4. The part of respondents (\%) that want more information. 


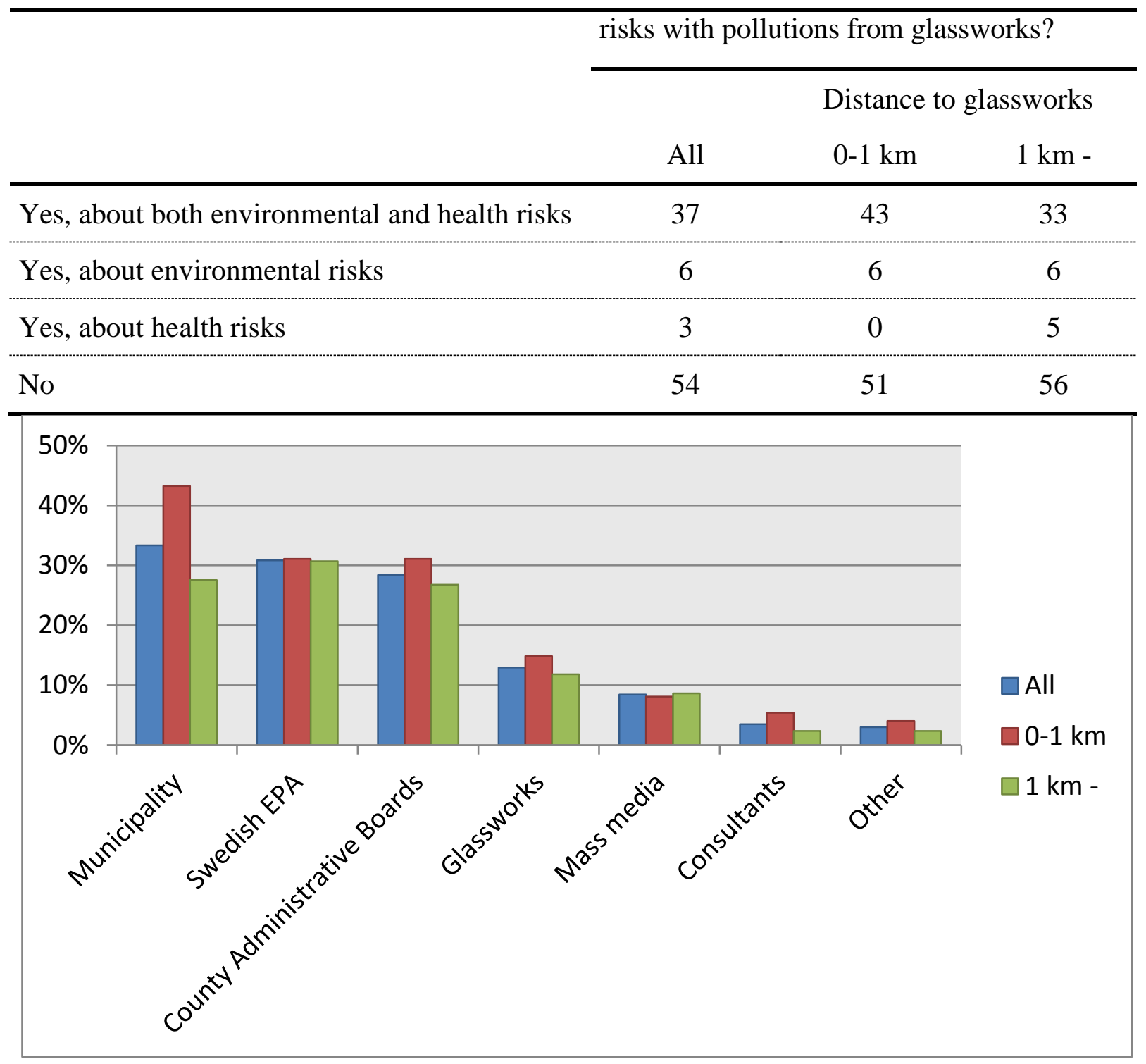

Figure 2. The part of respondents (\%) who gave the different answers to the question; who would you prefer inform about possible risks of pollution from glassworks? It was possible to choose multiple answers.

Mass media is a common way to bring out information about contaminated sites. But this was not the first choice for obtaining more information; the mass media was ranked after different authorities and glassworks (Figure 2). Less than 10\% stated that they wanted information from the mass media. This study does not further investigate how the public wants information. But since the result showed that as many as about half of the respondents wanted more information about environmental and health risks (Table 4), it would be useful to further examine how and in what form people want information in order to establish a successful risk communication.

After this study was performed in 2012, the situation with contaminated soils due to glassworks has been a theme in mass media several times. For example, in March 2014 it was reported that there was an increased frequency of some types of cancer near glassworks (e.g. www.svd.se 2014.03.17 and www.svt.se 2014.03.17). In July 2014 it was reported about 
elevated levels in some gardens around glassworks even though there was a focus on low concentrations of metals in ground water and vegetables (Smålandsposten 2014.07.03).

It is unclear how and if these messages in news media have affected the public risk perception. It cannot be excluded that several messages about risks with contaminated glass works sites through the news media after the performance of this study may have affected people's risk perception and worry. In order to establish an effective risk communication it is essential to understand people's perception of risks. A follow-up study about if and how risk perception has change over time and if messages in news media have affected people in this area together with information about how people want more information about possible risks with pollutions from glassworks would be valuable.

\section{CONCLUSIONS}

This study shows that especially those that lived close to glassworks perceived a high risk and were worried when it comes to glassworks contaminated soil in south-eastern Sweden. People perceived a higher risk and were in general more worried about risks for the environment than for human health (Table 1).

Many of the respondents consumed fruit and vegetables from their own garden or a garden nearby, it was only $18 \%$ of the respondents that lived $0-1 \mathrm{~km}$ from glassworks that stated that they never consumed fruit and 35\% stated that they never consumed vegetables from their own garden or a garden nearby (Table 2). The majority of respondents (94\%) that lived 0-1 $\mathrm{km}$ away from glassworks did not drink tap water from private wells (Table 3). The respondents were less worried about that fruit and vegetables should be affected by pollutions than for environmental and health risk in general. They were also less worried about that tap water should be affected by pollutions than affected fruit and vegetables (Table 1).

Even thought the respondents indicated that there were other environmental problems that were more serious than contaminated soil, the average score was high on the statement that it is important that soils contaminated by glassworks activities are cleaned up (Table 1). When it comes to information about risks, as many as nearly half of the respondent stated that they want more information (Table 4) and people mainly wanted information from authorities (Figure 2).

These results are useful as it is important to understand public risk perception and desire for more information in order to improve the exchange of information between authorities, consultants, researchers and the public, and thereby to establish a successful risk communication. But the results also revealed several areas that would be useful to investigate further. The study showed that many people wanted more information from authorities, but it would be valuable to investigate in more detail how people want information. The study also showed that many people consume home-grown fruit and vegetables. As our previous study concluded that there are high concentrations of lead and cadmium many gardens near glassworks [13], it is important to further investigate this exposure pathway.

\section{ACKNOWLEDGEMENTS}

This study was performed as a part of the research project Hållbart Glasrike (Sustainable Kingdom of Crystal) which is financed by the municipalities of Kalmar and Växjö. 


\section{REFERENCES}

[1] Naturvårdsverket (2012). Lägesbeskrivning av arbetet med avhjälpande av föroreningsskador 2012, Bilaga 2: Prioriterade och akuta objekt i landet 2011.

[2] Renn, O., 1990. Risk perception and risk management: A review. Part 2: Lessons for Risk Management. Risk Abstracts 7(2), 1-9.

[3] Sjöberg, L., 1998. Worry and risk perception. Risk Analysis 18(1), 85-93.

[4] Renn, O., 1990. Risk perception and risk management: A review. Part 1: Risk Perception. Risk Abstracts 7(1), 1-9.

[5] Slovic, P., 1987. Perception of risk. Science 236(4799), 280-285.

[6] Weber, O., Scholz, R.W. Bühlmann, R., Grasmück, D., 2001. Risk perception of heavy metal soil contamination and attitudes toward decontamination strategies. Risk Analysis 21(5), 967-977.

[7] Davidson, D.J., Freudenburg, W.R. 1996. Gender and Environmental Risk Concerns. A Review and Analysis of Available Research. Environment and Behavior 28(3), 302339.

[8] Gustafson, P.E. 1998. Gender differences in risk perception: Theoretical and methodological perspectives. Risk Analysis 18 (6), 805-811.

[9] Slovic, P. 1999. Trust, emotion, sex, politics, and science: Surveying the riskassessment battlefield. Risk Analysis 19(4), 689-701.

[10] Gutteling, J. M., Wiegman, O. 1993. Gender-Specific Reactions to Environmental Hazards in the Netherlands. Sex Roles 28(7-8), 433-447.

[11] Yim, M.S., Vaganov P.A. 2003. Effects of education on nuclear risk perception and attitude: Theory. Progress in nuclear energy 42(2), 221-235.

[12] Grasmück, D. Scholz, R.W. 2005. Risk perception of heavy metal soil contamination by high-exposed and low-exposed inhabitants: The role of knowledge and emotional concerns. Risk Analysis 25(3), 611-622.

[13] Augustsson, A., Uddh-Söderberg, T., Hogmalm, J., Filipsson, M., 2014. Metal uptake by homegrown vegetables - the relative importance in human health risk assessments at contaminated sites. Revised manuscript submitted to Environmental Research.

[14] Dudka, S., Miller W.P., 1999. Accumulation of potentially toxic elements in plants and their transfer to human food chain. Journal of Environmental Science and Health, Part B 34 (4), 681-708. 